\title{
Sandwich Enzyme-linked Immunosorbent Assay (ELISA) Analysis of Plant Cell Wall Glycan Connections
}

\author{
Valérie Cornuault ${ }^{\star}$ and J. Paul Knox
}

Centre for Plant Sciences, Faculty of Biological Sciences, University of Leeds, Leeds, UK

*For correspondence: bsvrc@leeds.ac.uk; J.P.Knox@leeds.ac.uk

[Abstract] Sandwich ELISA is a highly sensitive method that can be used to determine if two epitopes are part of the same macromolecule or supramolecular complex. In the case of plant cell wall glycans, it can reveal the existence of inter-polymers linkages, leading to better understanding of overall cell wall architectures. This development of a conventional sandwich ELISA protocol uses a carbohydrate-binding module (CBM), a small protein domain found in some carbohydrate catalysing or activating enzymes, and rat monoclonal antibodies (mAbs) which can be combined in the same ELISA plate without risk of cross reaction; the secondary anti-rat HRP antibody being only able to bind to the rat mAb and not the CBM (Figure 1). This protocol was developed and modified in the Prof. J. Paul Knox lab at the University of Leeds.

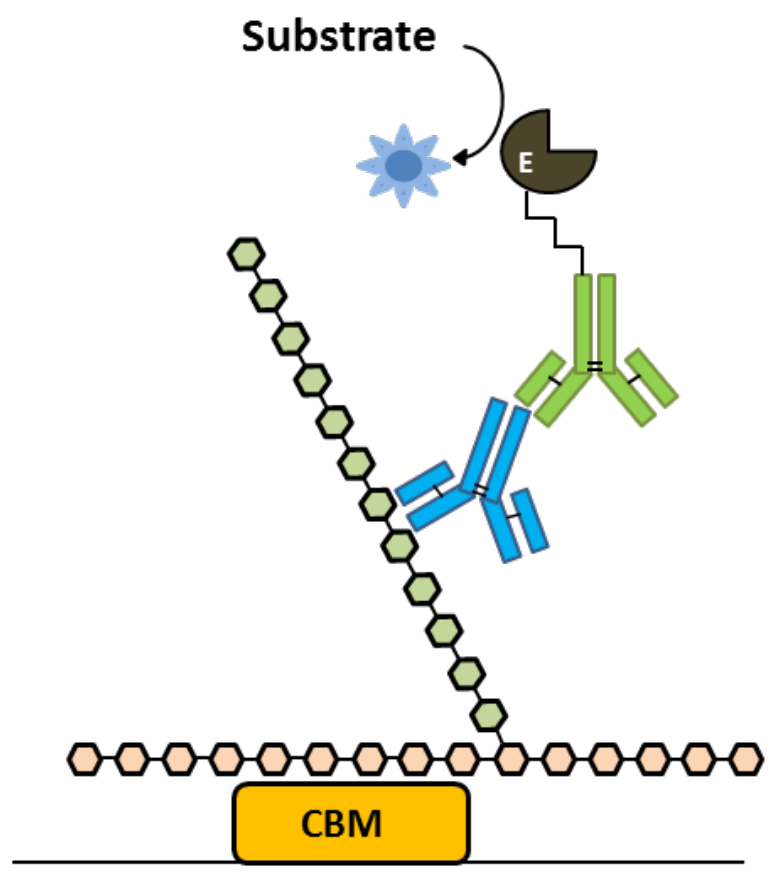

Figure 1. Sandwich ELISA analysis of complex glycans 


\section{Materials and Reagents}

1. Cell wall extracts (or purified cell wall polymers)

Notes:

a. Reagents for cell wall extracts are $50 \mathrm{mM}$ cyclohexanediamine tetraacetic acid (CDTA) (Sigma-Aldrich, catalog number: D1383) or $4 \mathrm{M} \mathrm{KOH/1 \%}$ (w/v) $\mathrm{NaBH}_{4}$ (Sigma-Aldrich, catalog number: 452882)

b. Cell wall extraction protocol using $4 \mathrm{M} \mathrm{KOH/1 \% (w/v)} \mathrm{NaBH}_{4}$ is described in Cid et al. (2010). This extraction will disrupt and release most cell wall glycans.

c. CDTA is a chelating agent which is used to specifically extract the pectin fraction from cell walls. The same protocol can be followed using $50 \mathrm{mM}$ CDTA instead of $4 \mathrm{M} \mathrm{KOH} \mathrm{(no} \mathrm{neutralizing} \mathrm{step} \mathrm{necessary).}$

2. Skimmed milk powder (Marvel Original) [used at $5 \%(w / v)$ in $1 \times$ PBS]

3. Purified recombinant carbohydrate-binding module (CBM)

Note: A protocol for CBM expression and purification can be found in Lee et al. (2013).

4. Primary monoclonal antibody (PlantProbes, www.plantprobes.net)

5. Secondary antibody (depending on the origin of the primary antibody used)

a. Anti-rat IgG-horseradish peroxidase (HRP)-conjugated (Sigma-Aldrich, catalog number: A9542)

b. Anti-mouse IgG-horseradish peroxidase (HRP)-conjugated (Sigma-Aldrich, catalog number: A6782)

6. $10 \mathrm{mg} / \mathrm{ml}$ tetramethyl benzidine (Sigma-Aldrich, catalog number: T2885)

7. $1 \mathrm{M}$ sodium acetate buffer $(\mathrm{pH} 6)$

8. $6 \% \mathrm{H}_{2} \mathrm{O}_{2}$ (VWR International, catalog number: $2858175 \mathrm{C}$ )

9. $2.5 \mathrm{M} \mathrm{H}_{2} \mathrm{SO}_{4}$ (VWR International, catalog number: $191675 \mathrm{~A}$ )

10. Tween 20 (Sigma-Aldrich, catalog number: P2287) (optional)

11. $1 x$ phosphate-buffered saline (PBS) (pH7) (see Recipes)

12. HRP developing solution (see Recipes)

\section{Equipment}

1. 96-well surface treated ELISA microtitre plates (Thermo Fisher Scientific, Nunc-Immnuno Maxisorp, catalog number: 442404)

2. Microtitre plate reader (450 $\mathrm{nm}$ absorbance) (Thermo Fisher Scientific, Multiskan ${ }^{\mathrm{TM}} \mathrm{FC}$ Microplate Photometer)

3. Multi-channel pipette (if available, not critical)

4. $\mathrm{pH}$ meter 


\section{Procedure}

1. Coat the microtitre plate using 0.5 to $1 \mu \mathrm{g} / \mathrm{ml} \mathrm{CBM}$ in $1 x$ PBS, $100 \mu \mathrm{l}$ per well at $4{ }^{\circ} \mathrm{C}$ overnight.

Note: The amount of CBM necessary to obtain a good signal will vary depending of its affinity to the substrate. Trials may be necessary to find the appropriate dilution.

2. Wash the plate 3 times using tap water or $1 \times$ PBS $0.1 \%(v / v)$ Tween 20 . Shake the plate dry.

Note: We routinely used tap water but one might prefer using 1x PBS $0.1 \%(v / v)$ Tween 20. The drying step is critical as any remaining water/buffer would dilute the next reagent. Make sure the plates are fully dried after each washing step.

3. Block the plate for $2 \mathrm{~h}$ using $5 \%(\mathrm{w} / \mathrm{v})$ milk powder in $1 \mathrm{x}$ PBS, $200 \mu \mathrm{l}$ per well at room temperature.

4. Wash the plate 3 times using tap water or $1 \times$ PBS $0.1 \%(v / v)$ Tween 20 . Shake the plate dry.

5. Incubate for 90 min with a cell wall extract or test glycan diluted in $5 \%(w / v)$ milk/1x PBS, $100 \mu \mathrm{l}$ per well at room temperature.

Note: Normal ELISA analysis can be used to determine which dilution of the extract gives the best signal. However, the amount of CBM used will determine the amount of glycan that can be immobilised. Therefore it is better to use more concentrated sample rather than less.

6. Wash the plate 6 times using tap water or 1 x PBS $0.1 \%(v / v)$ Tween 20 . Shake the plate dry.

7. Incubate with a primary antibody appropriately diluted in $5 \%(\mathrm{w} / \mathrm{v})$ milk/1x PBS, $100 \mu \mathrm{l}$ per well for $1 \mathrm{~h}$ at room temperature.

Note: Use 10x dilution of hybridoma cell culture supernatants if working with PlantProbes monoclonal antibodies.

8. Wash the plate 6 times using tap water or $1 \times$ PBS $0.1 \%(v / v)$ Tween 20 . Shake the plate dry.

9. Incubate with secondary HRP-conjugated antibody diluted $1: 1,000$ in $5 \%(w / v)$ milk/1x PBS, $100 \mu \mathrm{l}$ per well for $1 \mathrm{~h}$ at room temperature.

10. Wash the plate 9 times using tap water or 1 x PBS $0.1 \%(v / v)$ Tween 20 . Shake the plate dry.

Note: Plates should be thoroughly washed at this step to ensure no false positive signals due to non-specifically bound secondary antibody/HRP. 
11. Develop the plate using $150 \mu \mathrm{l}$ of substrate solution per well to detect secondary antibody binding. Let the plates develop for 5 to $10 \mathrm{~min}$. Stop the reaction by adding $50 \mu \mathrm{l}$ of $2.5 \mathrm{M}$ sulphuric acid.

Note: As developing the plate is a time dependent process it is important to ensure that all comparable samples are developed for the same time.

12. To collect the data, read the plates at $450 \mathrm{~nm}$ using the microtitre plate reader.

\section{Notes}

1. Make sure all experimental combinations in the microtitre plate wells are assayed in triplicates.

2. A control with no CBM (1x PBS) needs to be included in every experiment. This should remain blank if the plates are properly blocked. In case of a signal in no CBM wells increase the $\%$ of milk powder, block for longer or use $>3 \%$ Bovine Serum Albumin in place of milk powder.

\section{$\underline{\text { Recipes }}$}

1. $1 x$ phosphate-buffered saline (PBS) $(\mathrm{pH} 7)(1 \mathrm{~L})$

a. To prepare this buffer you need to add $\mathrm{NaH}_{2} \mathrm{PO}_{4}$ to 0.6712 moles/L and $\mathrm{Na}_{2} \mathrm{HPO}_{4}$ to 0.3288 moles/L.

b. The amount of acid and base is calculated using the Henderson-Hasselbalch equation $[\mathrm{pH}=\mathrm{pKa}+\log ($ Base $) /($ Acid $)]$.

c. Prepare just under a litre of the solution using the correct amounts of $\mathrm{NaH}_{2} \mathrm{PO}_{4}$ and $\mathrm{Na}_{2} \mathrm{HPO}_{4}$ in $\mathrm{dH}_{2} \mathrm{O}$.

d. Check the $\mathrm{pH}$ using a $\mathrm{pH}$ meter and adjust slightly if necessary using phosphoric acid or sodium hydroxide.

e. Once the $\mathrm{pH}$ is adjusted, bring the volume to $1 \mathrm{~L}$.

2. HRP developing solution $(50 \mathrm{ml})$

Mix $45 \mathrm{ml}$ of $\mathrm{dH}_{2} \mathrm{O}$ with $5 \mathrm{ml}$ of $1 \mathrm{M}$ sodium acetate buffer $(\mathrm{pH} 6)$

Add $500 \mu \mathrm{l}$ of tetramethyl benzidine

At the last minute add $50 \mu \mathrm{l}$ of $6 \% \mathrm{H}_{2} \mathrm{O}_{2}$

Note: Adding hydrogen peroxide starts the reaction. It is therefore important to add it at the last minute to avoid high background signal. 


\section{Acknowledgments}

The research leading to this protocol has received funding from the European Union Seventh Framework Programme (FP7 2007-2013) under the WallTraC project (Grant Agreement $n$ 263916). This article reflects the author's views only. The European Community is not liable for any use that may be made of the information contained herein.

\section{References}

1. Cid, M., Pedersen, H. L., Kaneko, S., Coutinho, P. M., Henrissat, B., Willats, W. G. and Boraston, A. B. (2010). Recognition of the helical structure of beta-1,4-galactan by a new family of carbohydrate-binding modules. J Biol Chem 285(46): 35999-36009.

2. Lee, K. J., Cornuault, V., Manfield, I. W., Ralet, M. C. and Knox, J. P. (2013). Multi-scale spatial heterogeneity of pectic rhamnogalacturonan I (RG-I) structural features in tobacco seed endosperm cell walls. Plant J 75(6): 1018-1027. 